\title{
Correction to: Cell salvage processing of residual cardiopulmonary bypass volume in minimally invasive cardiac surgery
}

\author{
Ryosuke Muraki ${ }^{1}$ Toshinori Totsugawa ${ }^{2}$ (1) $\cdot$ Kazuyuki Nagata $^{1} \cdot$ Kosuke Nakajima $^{1} \cdot$ Tomoya Oshita $^{1}$. \\ Masahisa Arimichi ${ }^{1} \cdot$ Hidenori Yoshitaka $^{2} \cdot$ Taichi Sakaguchi $^{2}$
}

Published online: 6 April 2019

๑) Springer Japan KK, part of Springer Nature 2019

\section{Correction to: Heart and Vessels https://doi.org/10.1007/s00380-019-01365-6}

In the article "Cell salvage processing of residual cardiopulmonary bypass volume in minimally invasive cardiac surgery" published in Heart and Vessels, there were several errors in numerical values.

A list of errata is as follows:

In section "Processing of residual blood and blood sampling" appearing under heading "Patients and methods", "200 $\mathrm{ml}$ saline" appearing in the last sentence of the first paragraph has to be read as " $500 \mathrm{ml}$ saline".

In section "Patients' demographic characteristics" appearing under heading "Results", " $17,743 \pm$ vs. 18,440 $\pm \times 10^{3} / \mu \mathrm{l}$ " formula has to be read as " $177 \pm 43$ vs. $184 \pm$ $40 \times 10^{3} / \mu \mathrm{l}$.

In section "Intraoperative data during CPB" appearing under heading "Results", (control group, 26,463 $\pm \mathrm{ml}$ vs. CS group, $23,854 \pm \mathrm{ml}$ ) should be read as (control group, $264 \pm 63 \mathrm{ml}$ vs. CS group, $238 \pm 54 \mathrm{ml}$ ).

Under Table 2, data appearing in column 2 and 3 for CPB time (min) was published incorrectly as $15 \pm 122$ and $15 \pm$ 025 the correct data must read as $151 \pm 22$ and $150 \pm 25$. And tha data appearing in Mechanical valve/tissue valve, is incorrectly published as $34 / 6$ and $37 / 3$ the correct data is $6 / 34$ vs. $3 / 37$.

The original article can be found online at https://doi.org/10.1007/ s00380-019-01365-6.

Toshinori Totsugawa

toshinoritotsugawa@gmail.com

1 Department of Clinical Engineering, The Sakakibara Heart

Institute of Okayama, Okayama, Japan

2 Department of Cardiovascular Surgery, The Sakakibara Heart Institute of Okayama, 2-5-1, Nakai-cho, Kita-ku, Okayama 700-0804, Japan
Also, In Table 4 Postoperative blood loss and use of blood products, data appearing in column 2 and 3 for $6 \mathrm{~h}$ after admission to ICU was published incorrectly as $115 \pm 50$ and $733 \pm 3$, the correct data must be read as $115 \pm 50$ and $73 \pm 33$.

Publisher's Note Springer Nature remains neutral with regard to jurisdictional claims in published maps and institutional affiliations. 